\title{
Bagaimana Intellectual Capital Mempengaruhi Kinerja Perusahaan Pada Perbankan Di Indonesia?
}

\author{
Fangky A. Sorongan \\ Perbanas Institute, Jakarta \\ Email:f.sorongan@perbanas.id
}

\begin{abstract}
Abstrak
Perusahaan yang sukses adalah perusahaan yang terus berinovasi, mengandalkan teknologi baru dan menekankan pada keterampilan dan pengetahuan karyawan. Nilai tambah dapat dihasilkan dari sebuah aset yang tidak berwujud yang tidak selalu tercermin dalam laporan keuangan. Oleh karena itu, penelitian ini mencoba untuk menyelidiki pengaruh Intellectual Capital dan kinerjanya pada Bank di Indonesia. Hasil penelitian didasarkan pada data yang diambil dari 16 Bank Umum Swasta Nasional Devisa (BUSND) yang terdaftar di BEI periode tahun 2015-2019. Ditemukan bahwa Intellectual Capital memiliki hubungan yang signifikan dan positif dengan kinerja perusahaan yang diukur dengan profitabilitas dan Return on Assets (ROA). Hasil penelitian menunjukan secara parsial menunjukan bahwa HCE, CEE dan SCE berpengaruh signifikan terhadap ROA, sedangkan model VAIC (HCE, CEE dan SCE) secara bersama-sama berpengaruh signifikan terhadap ROA.
\end{abstract}

Kata Kunci: Intellectual Capital; ROA; VAIC; Bank

\section{Pendahuluan}

Diseluruh negara sistem keuangan yang sehat sangat penting bagi perekonomian untuk beroperasi dan tumbuh berkembang. Terlebih sistem keuangan di sektor perbankan secara luas dianggap sebagai sektor yang paling berpengaruh Haris et al. (2019). Di tahun 1998, Indonesia pernah merasakan dampak krisis moneter yang sangat luar biasa dimana tingkat pertumbuhan PDB menyentuh -13,6 dengan tingkat pertumbuhan inflasi 65\% sehingga menghambat pertumbuhan industri di masa lalu. Namun, secara perlahan kini sektor perbankan telah tumbuh seiring dengan pertumbuhan ekonomi Indonesia. Peningkatan kinerja sektor perbankan tetap signifikan mengingat pentingnya bagi perekonomian. Peningkatan kinerja tentunya dapat dipengaruhi dari berbagai pihak seperti pembuat kebijakan, regulator, manajemen bank dan kinerja keuangan. Saat ini Bank yang modern beroperasi dalam lingkungan yang lebih dinamis dan menantang karena persaingan yang ketat, kebiasaan konsumen yang berubah-ubah, kemajuan teknologi, dan inovasi berkelanjutan dalam sistem dan proses.

Kinerja keuangan sangat dibutuhkan oleh suatu industri untuk mengetahui dan mengevaluasi sampai dimana tingkat keberhasilan industri berdasarkan aktivitas keuangan yang telah dilaksanakan Appuhami (2007). Meskipun Nadeem et al. (2018) menyatakan bahwa pos-pos neraca bukanlah satu-satunya dasar untuk menciptakan nilai melainkan item nonneraca seperti informasi, pengetahuan, kekayaan intelektual, keahlian, sistem, dan proses juga memiliki relevansi penciptaan nilai yang signifikan bagi sebuah perusahaan. Laporan kinerja keuangan merupakan bagian dari dokumen perusahaan yang penting Ozkan et al. (2016). Selain itu, keberhasilan perusahaan juga bisa di dorong dengan kemajuan teknologi informas di era digital dimana informasi sebagai pusat sumber daya di dunia dengan berbasis 
pengetahuan Mondal \& Ghosh (2012). Banyak perusahaan di era ekonomi modern saat ini tidak lagi bergantung pada aset fisik, melainkan pada aset yang tidak berwujud atau Intellectual Capital (IC). Sehingga untuk meningkatkan kinerja keuangan dibutuhkan Intellectual Capital (IC) Kannan \& Aulbur (2004). IC merupakan kontributor vital bagi kinerja perusahaan Nadeem et al. (2018). Celenza \& Rossi (2014) menyatakan bahwa perusahaan yang mengelola IC akan lebih efektif mampu mengamankan keunggulan kompetitif yang sangat kuat dan berkinera lebih baik atas perusahaan lain. Aslam \& Haron (2020); Garcia-Perez et al. (2020); Ousama et al. (2019) berpendapat bahwa IC adalah merupakan sekumpulan aset tidak berwujud yang dapat meningkatkan kinerja perusahaan serta nilai dari perusahaan.

Ada banyak penelitian dan literatur secara empiris mendukung peran IC yang dapat mempengarui terhadap kinerja keuangan perusahaan Guthrie \& Petty (2000); Firer \& Mitchell Williams (2003); Tunc Bozbura (2004); Bollen et al. (2005); Shiu (2006); Nazari \& Herremanas (2007); Tan et al. (2007); Do Rosário Cabrita \& Bontis (2008); Inkinen (2015); Asiaei \& Jusoh (2015); Sidharta \& Affandi (2016); Scafarto (2016); Dzenopoljac et al. (2017); Smriti \& Das (2018); Nadeem et al. (2018); Bayraktaroglu et al. (2019); Salinas-Ávila et al. (2020); Ramírez et al. (2020). Meski demikian, studi tersebut akan selalu menjadi hal yang menarik untuk diungkapkan. Studi ini melanjutkan dan memperluas penelitian yang sudah dikembangkan sebelum nya untuk mengungkap lebih lanjut untuk melihat hubungan antara IC dengan kinerja perusahaan dengan melihat dari sudut pandang kinerja keuangan.

Tran et al. (2020) menyatakan bahwa IC merupakan asset tidak berwujud, yang berisi informasi dan pengetahuan yang dimiliki badan usaha yang harus dikelola dengan baik. IC dapat memberikan keunggulan kompetitif bagi perusahaan (Subanidja et al, 2020); (Klein \& Prusak, 1994). Lebih lanjut Pulic (2004) mengatakan keberhasilan suatu perusahaan bergantung pada kemampuan pemanfaatan pengetahuan. Untuk mengukur IC dibutuhkan Metode value added intellectual coefficient (VAIC) Metode ini dimulai dengan kemampuan perusahaan untuk menciptakan value added (VA) Pulic (2000). Pendekatan ini relatif mudah dan sangat mungkin untuk dilakukan, karena dikonstruksi dari akun-akun dalam laporan keuangan perusahaan (Brennan, 2001). Model VAIC Pulic telah banyak digunakan dalam penelitian serta dalam praktik perusahaan untuk mengukur efisiensi IC Nadeem et al. (2018). Selanjutnya Pulic (2004) menyatakan bahwa model VAIC adalah dapat dianggap tepat dan obyektif untuk menilai keberhasilan bisnis dan menunjukkan kemampuan perusahaan dalam penciptaan Value Added (VA).

Tujuan penelitian ini adalah untuk mengungkap hubungan antara IC dengan kinerja keuangan perusahaan sektor Bank di Indonesia dengan pendekatan model VAIC. Industri perbankan Indonesia dipilih salah satu sektor yang paling intensif dalam penggunaan Intellectual Capital. Berbeda dengan industri manufaktur, keberhasilan operasional, pertumbuhan, dan profitabilitas bank tidak bergantung pada aset fisik (Haris et al, 2019). Dalam beberapa tahun terakhir, lembaga keuangan, terutama yang bergerak di industri perbankan memiliki lingkungan yang dinamis dan kompetitif. Sebagai indikator kinerja keuangan digunakan adalah Return on Asset (ROA) untuk menganalisa model statistik mewakili rasio profitabilitas.

\section{Landasan Teori}

\section{Intellectual capital}

Definisi Intellectual Capital (IC) telah banyak diungkapkan oleh beberapa peneliti. Bontis (1998) menyebutkan Intellectual capital adalah hasil dari proses transformasi pengetahuan yang menciptakan aset yang bernilai bagi perusahaan. Sedangkan Guthrie et al. (2001) menyatakan bahwa IC merupakan dapat menjadi basis kompetensi inti bagi perusahaan 
dan dapat mempengaruhi daya tahan dan keunggulan bersaing. Intellectual Capital sebagai nilai ekonomi dari dua kategori intangible asset, yaitu organizational (structural capital) dan human capital (Isola, Adeleye and Olohunlana, 2020). Roslender \& Fincham (2004) menyatakan IC dapat diidentifikasi dari selisih antara nilai pasar industri dengan nilai buku dari aset industri. Sedangkan menurut Lari Dashtbayaz et al. (2020) IC dianggap sebagai sumber informasi disaat era keterbukaan saat ini yang dapat mewakili dari kemampuan perusahaan. Lebih lanjut Shahwan \& Habib (2020) menyatakan bahwa IC dapat meningkatkan kinerja keuangan dan mengurangi kemungkinan terjadinya financial distress.

\section{Komponen Model VAIC}

Pulic (2000) menyatakan Intellectual Capital (IC) memiliki tiga komponen yaitu Efisiensi sumber daya manusia (HCE), efisiensi struktural modal (SCE) dan efisiensi penggunaan modal (CEE). Lebih lanjut Pulic (2004) menjelaskan HCE merupakan kombinasi knowledge, skill, innovativeness, dan kemapuan individu dalam suatu industri, selanjutnya (SCE) merupakan kemampuan organisasi mencakup infrastruktur, sistem informasi, rutinitas, prosedur dan budaya organisasi yang mendukung usaha karyawan untuk menghasilkan intelektual yang optimal, sedangkan CEE merupakan hubungan yang harmonis dengan para mitranya. Masih dalam Pulic (2000) untuk menghasilkan Value Added (VA) (nilai tambah) dapat dihitung dari laporan keuangan Bank. Nilai tambah (VA) dihitung sebagai selisih antara keluaran dan masukan.

Nilai tambah $(V A)=$ Output - Input, di mana Output didefinisikan sebagai pendapatan kotor perusahaan dan Input didefinisikan sebagai biaya operasi perusahaan tidak termasuk biaya tenaga kerja.

$\mathrm{VA}=$ Total Operating Income $(\mathrm{TOI})-$ Total Operating Expense $(\mathrm{TOE})+$ Personnel Expenses dimana TOI = Interest Income - Interest Expense, , Other Administrative Expenses + Other Operating Expenses

\section{+ Loan Loss Provisions}

Komponen pertama masih dalam Pulic (2000), yang termasuk dalam komponen HCE (human capital efeciency) adalah beban gaji (total gaji) perusahaan Beban gaji karyawan dianggap bukan merupakan biaya tetap namun masuk dalam sebuah investasi.

Efisiensi sumber daya manusia dihitung dengan rumus: $\quad H C E=\frac{V A}{H C}$

dimana: $\mathrm{HCE}=$ koefisien efisiensi sumber daya manusia bagi perusahaan; VA = nilai tambah; $\mathrm{HC}=$ total gaji atau upah perusahaan. Berdasarkan penelitian yang di lakukan oleh Mondal \& Ghos (2012); Dzenopoljac et al. (2017); Nadeem et al. (2018); Wang et al. (2018) menyatakan HCE dapat mempengaruhi terhadap profitabilias (ROA). Semakin stinggi nilai HCE perusahaan juga akan diikuti dengan pengelolaan Intellectual Capital perusahaan semakin efisien sehingga berdampak dalam meningkatkan profitabilitas perusahaan.

Komponen kedua dalam IC adalah struktur capital yang dihitung dengan rumus sebagai berikut:

$$
S C E=\frac{S C}{V A}
$$

dimana: $\mathrm{SCE}=$ efisiensi struktural modal bagi perusahaan; $\mathrm{SC}=$ struktural modal; $\mathrm{VA}=$ nilai tambah. 
SCE merupakan perbandingan antara struktur modal dengan nilai tambah. Ketika perusahaan dapat melakukan efisiensi akan berdampak pada operasional sehingga meningkatkan profit perusahaan Dzenopoljac et al. (2017); Ousama et al. (2019); Ting et al. (2020).

Komponen ketiga dari IC adalah CEE (capital employed efeciency). IC tidak dapat menciptakan nilai dengan sendirinya, sehingga diperlukan informasi mengenai efisiensi modal yang digunakan yang dapat dihitung dengan cara sebagai berikut:

$$
C E E=\frac{V A}{C E}
$$

dimana: $\mathrm{CEE}=$ efisiensi penggunaan modal; $\mathrm{VA}=$ nilai tambah $; \mathrm{CE}=$ nilai buku aset bersih perusahaan. Ketika perusahaan dapat melakukan efisiensi dalam penggunaan modal nya, sehingga modal dapat diputar dan digunakan untuk pengembangan lain, sehingga akan menghasilkan keuntungan bagi perusahaan (Nadeem et al, 2018); (Dzenopoljac et al, 2017); (Wang et al, 2018); (Ousama et al, 2019).

VAIC merupakan indikator gabungan dari secara keseluruhan perusahaan. VAIC mengukur seberapa banyak nilai baru yang dapat diperoleh oleh perusahaan yang diinvestasikan. Efisiensi yang tinggi menunjukkan penciptaan nilai yang lebih tinggi dengan menggunakan sumber daya perusahaan, termasuk modal intelektualnya. Semakin tinggi VAIC dapat mempengaruhi kinerja perusahaan dalam hal teknologi dan berbasis ilmu pengetahuan sehingga dapat mempengarui profit perusahaan (ROA) (Celenza \& Rossi, 2014); (Smriti and Das, 2018); (Bayraktaroglu et al, 2019).

$$
\mathrm{VAIC}=\mathrm{HCE}+\mathrm{CEE}+\mathrm{SCE}
$$

\section{Hubungan Intellectual Capital dan Kinerja Keuangan}

Beberapa penelitian secara empiris telah dilakukan yang membuktikan bahwa IC dengan pendekatan model VAIC mempunyai pengaruh yang signifikan terhadap kinerja perusahaan diberbagai negara. Seperti Chen, Cheng and Hwang (2005); Chang (2007); Wang et al. (2018); Bayraktaroglu, Calisir and Baskak (2019) hasil penelitian nya menyatakan terdapat hubungan antara kinerja keuangan ROA dipengaruhi oleh IC dengan menggunakan pendekatan model VAIC. Selain itu Shiu, (2006); Dzenopoljac et al. (2017) berpendapat bahwa IC (model VAIC) menunjukkan bahwa ada hubungan positif yang signifikan antara dengan kinerja keuangan dengan indikator ROE, ROA, GR. Bahkan Ousama, Hammami and Abdulkarim (2019) dalam penelitian nya menyatakan IC memiliki hubungan yang positif dan signifikan terhadap indikator ROA ROE, ATO, PBV sehingga dapat memberikan kontribusi terhadap kinerja keuangan perusahaan. Return on Asset (ROA) adalah salah satu indikator keberhasilan perusahaan untuk menghasilkan laba sehingga semakin tinggi profitabilitas maka semakin tinggi kemampuan untuk menghasilkan laba bagi perusahaan (Sorongan, 2016); (Sorongan, 2019).

Oleh karena itu pada penelitian ini menggunakan variabel dependen rasio profitabilitas Return On Assets (ROA) dengan rumus:

$$
R O A=\frac{\text { Laba Bersih }}{\text { Total Aset }}
$$




\section{Hubungan Intellectual Capital dengan Industri Perbankan}

Penelitian secara empiris yang menguji hubungan IC dengan industri perbankan telah banyak di lakukan. Seperti Pulic (2004) mengungkapkan bahwa pentingnya IC bagi bank-bank di negara Australia, ditemukan terdapat interaksi yang dominan diantara IC dan Bank. Studi lain dilakukan oleh Herrera Rodríguez and Ordóñez-Castaño (2020) menguji keterkaitan antara komponen IC dengan kinerja bank pada bank Panama dan Colombia menyimpulkan struktural modal dan kinerja perusahaan dapat dipengarui oleh IC dengan model intelektual (VAIC). Gigante (2013) melakukan penelitian bank di Eropa, hasilnya menunjukkan bahwa ada hubungan yang kuat antara IC dengan kinerja keuangan bank serta menegaskan bahwa IC merupakan sumber utama yang dapat memberikan keuntungan profitabilitas (ROA) bank. Namun studi lain yang di lakukan oleh Puntilo (2019) hubungan dengan VAIC dengan Bank di Italia menunjukkan hasil yang berbeda dengan mengukur kinerja keuangan dengan rasio ROA dan ROE dimana menghasilkan tidak ada hubungan yang terkait. Muhammad and Ismail (2009) meneliti hubungan tersebut antara IC dan kinerja organisasi dari 18 perusahaan perbankan di Malaysia mengungkapkan bahwa kinerja keuangan bank yang baik tidak terlalu ditentukan oleh efisiensi IC.

Berdasarkan kajian teori yang telah diuraikan, maka hipotesis dalam penelitian ini dapat dirumuskan sehagai berikut :

$\boldsymbol{H}_{1}:$ Human Capital Efeciency (HCE) berpengaruh terhadap ROA

$H_{2}$ : Capital Employed Efeciency (CEE) berpengaruh terhadap ROA

H3: Structural Capital Efeciency (SCE) berpengaruh terhadap ROA

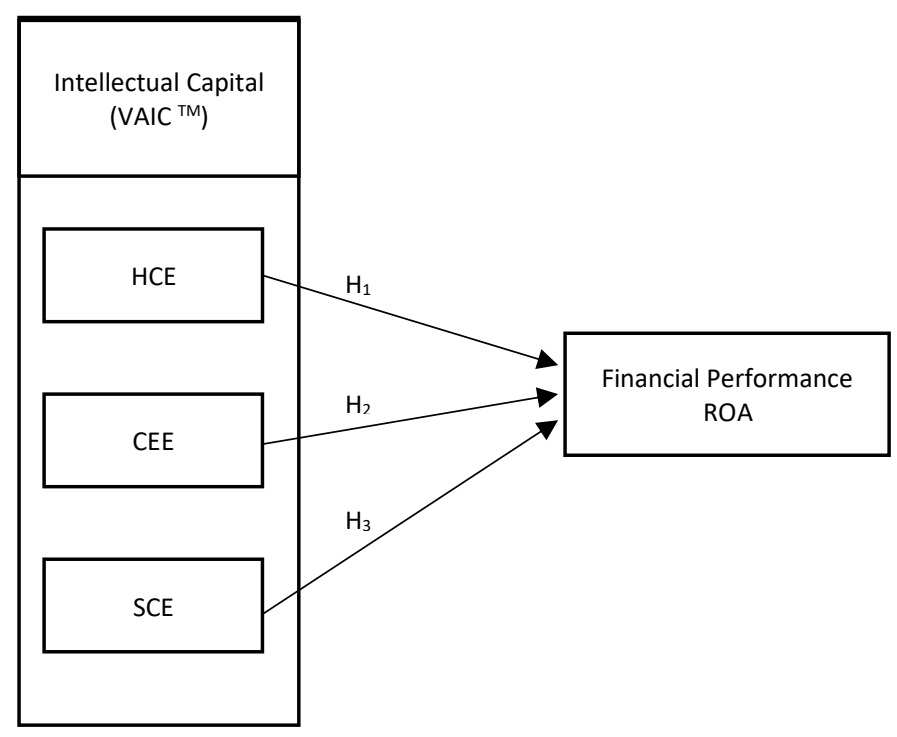

Gambar 1 Kerangka Pemikiran

\section{Metode Penelitian}

Populasi dalam penelitian ini sebanyak 31 Bank Umum Swasta Nasional Devisa (BUSND) dengan periode 2015-2019 yang bersumber pada Otoritas Jasa Keuangan (OJK). Kriteria sampel yang digunakan adalah telah terdaftar di BEI selama periode 2015-2019, BUSND mempublikasikan laporan keuangan tahunannya di BEI selama periode 2015-2019. Dari populasi sebanyak 31 Bank Umum Swasta Nasional Devisa yang terdaftar di BEI pada tahun 2015-2019, terdapat 16 bank yang memenuhi kriteria sampel penelitian ini. 
Menggunakan analisis statistik dekriptif, uji asumsi klasik, uji hipotesis dan analisis yang digunakan pada penelitian ini adalah regresi data panel dengan menggunakan sistem Eviews.

\section{Pembahasan}

Berdasarkan Tabel 2 dapat dilihat bahwa nilai rata-rata ROA, HCE, CEE, SCE memiliki nilai yang lebih besar dari standar deviasi nya sehingga sebaran nilai ROA, HCE, CEE, SCE dianggap baik.

Tabel 2 Statistik Deskriptif

\begin{tabular}{|l|c|c|c|c|}
\hline & ROA & HCE & CEE & SCE \\
\hline Mean & 1.982554 & 0.382988 & 1.681905 & 0.348647 \\
\hline Median & 2.107695 & 0.261927 & 1.833194 & 0.454401 \\
\hline Maximum & 5.1595104 & 1.026367 & 2.546718 & 0.607338 \\
\hline Minimum & 0.671005 & 0.133102 & 1.001155 & 0.001154 \\
\hline Std. Dev. & 0.114927 & 0.257110 & 0.489102 & 0.205641 \\
\hline Observations & 80 & 80 & 80 & 80 \\
\hline
\end{tabular}

Sumber: Data diolah (2021)

\section{Pemilihan Estimasi Model}

Untuk menentukan model yang akan digunakan dalam penelitian ini, dilakukan uji dan tahapan untuk mendapatkan model yang cocok melakukan uji F, dan uji hausman.

Tabel 3 Uji F

\begin{tabular}{|l|c|c|c|}
\hline Effects Test & Statistic & d.f. & Prob. \\
\hline Cross-section $\boldsymbol{F}$ & 36.119000 & $(5,27)$ & 0.0000 \\
\hline $\begin{array}{l}\text { Cross-section } \\
\text { Chi-square }\end{array}$ & 73.431079 & 5 & 0.0000 \\
\hline
\end{tabular}

Sumber: Data diolah (2021)

Berdasarkan Tabel 3 nilai probabilitas dari F statistik adalah 0,0000, hasil ini lebih kecil dari 0,05 sehingga menolak $\mathrm{H}_{0}$ yang artinya metode data panel yang digunakan adalah model fixed effect

Tabel 4 Uji Hausman

\begin{tabular}{|l|c|c|c|}
\hline Test Summary & $\begin{array}{c}\text { Chi-Sq. } \\
\text { Statistic }\end{array}$ & Chi-Sq. d.f. & Prob. \\
\hline Cross-section random & 2.685741 & 3 & 0.4427 \\
\hline
\end{tabular}

Sumber: Data diolah (2021)

Berdasarkan Tabel 4 Nilai probabilitas dari F statistik di atas adalah 0,4427, hasil ini lebih besar dari 0,05 sehingga menerima $\mathrm{H}_{0}$ yang artinya metode data panel yang digunakan adalah model Random Effect. 
Tabel 5 Uji Mulitikolinearitas

\begin{tabular}{|l|c|c|c|}
\hline & HCE & CEE & SCE \\
\hline HCE & 1 & -0.491524976 & -0.626015411 \\
\hline CEE & -0.491524976 & 1 & 0.892198374 \\
\hline SCE & -0.626015411 & 0.892198374 & 1 \\
\hline
\end{tabular}

Sumber: Data diolah (2021)

Berdasar Tabel 5, semua variabel terbebas dari multikoliniearitas karena seluruh variabel independen bernilai $<1$.

Tabel 6 Uji t

\begin{tabular}{|c|c|c|c|c|}
\hline Variable & Coefficient & Std. Error & t-Statistic & Prob. \\
\hline C & 0.139711 & 0.073006 & 1.913705 & 0.0646 \\
\hline HCE & 0.413605 & 0.087118 & 4.747644 & 0.0000 \\
\hline CEE & 0.056382 & 0.077204 & 0.730301 & 0.0021 \\
\hline SCE & 0.609764 & 0.249508 & 2.443867 & 0.0301 \\
\hline R-squared & 0.713537 & Mean dependent var & 0.016467 \\
\hline S.E. of regression & 0.696715 & S.D. dependent var & 0.046223 \\
\hline F-statistic & 0.030071 & \multicolumn{2}{|l|}{ Sum squared resid } & 0.028936 \\
\hline Prob(F-statistic) & 16.89999 & \multicolumn{2}{|l}{ Durbin-Watson stat } & 1.229148 \\
\hline Substed R-squared & 0.000001 & \multicolumn{3}{|l}{} \\
\hline
\end{tabular}

Sumber: Data diolah (2021)

Berdasarkan Tabel 6, variabel HCE menghasilkan nilai signifikansi koefisien sebesar sebesar 0,413605 dengan probabilitas sebesar $0,0000<0,05$ sehingga terdapat pengaruh yang signifikan positif antara HCE terhadap ROA. Variabel CEE menghasilkan nilai signifikasi koefisien sebesar 0,056382 dengan probabilitas sebesar 0,0021 $<0,05$, sehingga dapat disimpulkan bahwa terdapat pengaruh yang signifikan antara CEE terhadap ROA. Variabel SCE menghasilkan nilai signifikasi koefisien sebesar 0.609764 dengan probabilitas sebesar $0,0301<0,05$ sehingga dapat disimpulkan bahwa terdapat pengaruh yang signifikan antara SCE terhadap ROA.

\section{Uji F}

Hasil Uji F berdasarkan Tabel 3, nilai F-statistic menghasilkan probabilitas sebesar $0,000001<0,005$ sehingga dapat disimpulkan variabel independen yaitu HCE, CEE dan SCE secara simultan berpengaruh secara signifikan positif terhadap ROA.

\section{Uji Determinasi $\left(\mathbf{R}^{2}\right)$}

Berdasarkan Tabel 6, diketahui bahwa kontribusi keseluruhan variabel independen terhadap variabel dependen yang dinyatakan dengan nilai Adjusted R Square adalah sebesar 0,696 atau 69,6\%. Angka ini dapat menjelaskan bahwa 69,6\% variabel ROA dipengaruhi oleh ketiga variabel independen, yaitu HCE, CEE dan SCE. Sedangkan sisanya sebesar 30,4\% dikontribusikan oleh faktor lain di luar variabel penelitian

Berdasarkan Tabel 6, nilai probabilitas variabel HCE 0,0000 $<0,05$, sehingga dapat disimpulkan bahwa variabel HCE dapat mempengaruhi secara signifikan terhadap ROA, sehingga $\mathrm{H}_{1}$ diterima. Human Capital Efeciency dihitung dengan membandingkan nilah tambah dengan beban total gaji karyawan. Hasil penelitian ini dapat meyimpulkan bahwa 
perusahaan dalam hal ini Bank (BUSND) masih percaya dan berfokus berinvestasi pada aset yang tidak berwujud yaitu pengembangan pengetahuan dan skill kepada karyawan bank. Perusahaan banyak berharap melalui investasi kepada karyawan melalui dengan bakat dan ketrampilan serta pengetahua karena perusahaan menyadari penting betapa pentingnya dalam pengelolaan sumber daya manusia bila digunakan secara efisien akan banyak berkontribusi pada peningkatan kinerja performa Bank serta meningkatkan motivasi karyawan atau untuk memungkinkan karyawan menghasilkan ide-ide baru, produk baru, proses bisnis baru sehingga bank dapat lebih berkompetitif dengan para pesaing sehingga diharapkan dapat meningkatkan profitabilitas (ROA). Hasil penelitian ini didukung dan sejalan yang dilakukan oleh Mondal \& Ghosh (2012); Dzenopoljac et al. (2017); Nadeem et al. (2018); Wang et al. (2018) menyatakan HCE dapat mempengaruhi terhadap profitabilias (ROA). Namun, hasil penelitian ini tidak sejalan dengan penelitian yang dilakukan oleh Smriti and Das (2018); Dalwai and Mohammadi (2020) yang menyetakan HCE tidak berpengaruh kepada ROA dikarenakan perusahaan gagal dan belum menyadari pentingnya sumber daya manusia.

Berdasarkan Tabel 6 , nilai probabilitas variabel CEE 0,0021<0,05, sehingga dapat disimpulkan bahwa variabel CEE dapat mempengaruhi secara signifikan terhadap ROA, sehingga $\mathrm{H}_{2}$ diterima. Capital Employed Efeciency di hitung dengan membandingan nilai tambah dengan nilai buku aset bersih perusahaan. Hasil penelitian ini menyimpulkan betapa pentingnya IC harus dikombinasikan dengan dengan aset keuangan dan non-keuangan untuk menciptakan nilai bagi perusahaan. Dengan modal yang kuat dapat membantu Bank untuk menjaga kelangsungan hidup dan bisa berkompetisi di pasar setia saat. Hasil peneliti ini di dukung oleh Chen, Danbolt and Holland (2014); Dzenopoljac et al. (2017); Wang et al. (2018), namun tidak didukung dengan penelitian Ozkan, Cakan and Kayacan (2016) yang menyatakan bahwa CEE kurang efektif dalam menciptakan nilai di sektor perbankan.

Berdasarkan Tabel 6, nilai probabilitas variabel SCE $0,0301<0,05$, sehingga dapat disimpulkan bahwa variabel SCE dapat mempengaruhi secara signifikan terhadap ROA, sehingga $\mathrm{H}_{3}$ diterima. Structural Capital Efeciency dihitung dengan membandingkan struktur modal dengan nilai tambah. Hasil penelitian menyimpulkan bahwa ketika perusahaan mampu melalukan efisiensi sehingga akan mendapatkan nilai tambah yang memberikan manfaat ekonomi jangka panjang bagi Bank dalam persaingan binis dengan bank lain sehingga akan meningkatkan keuntungan bagi perusahaan. Hasil penelitian ini sejalan dan didukung oleh Dzenopoljac et al. (2017); Ousama et al. (2019) namun, hasil penelitian ini tidak didukung oleh Mondal \& Ghosh (2012).

Berdasarkan Tabel 6, nilai F-statistic menghasilkan probabilitas sebesar 0,000001 < 0,005 sehingga dapat disimpulkan variabel independen yaitu Model VAIC yang terdiri dari HCE, CEE dan SCE secara simultan berpengaruh secara signifikan positif terhadap ROA, sehingga $\mathrm{H}_{4}$ diterima.

Dengan menggunakan Model VAIC dapat ditemukan korelasi antara IC dengan kinerja keuangan pada perusahaan. VAIC mampu mendefinisikan aktivitas bisnis sebagai nilai tambah dan keuntungan bagi Bank. Beberapa cara dapat dicapai melalui penciptaan nilai pada aset yang tidak berwujud seperti komunikasi, membangun hubungan dengan pelanggan serta membangun dan memelihara reputasi bank dengan baik. Sebab dalam metode akuntansi tradisional dalam menilai perusahaan tidak dapat melakukan berbasis pengetahuan yang merepresentasikan informasi yang terkandung dalam laporan mengenai kondisi eksternal (keseimbangan lingkungan), faktor sosial (keseimbangan sosial) dan faktor-faktor yang secara khusus berkaitan dengan daya saing (keseimbangan tidak berwujud), sehingga tidak dapat mewakili entitas entitas yang hanya terkait dengan kinerja keuangan dan ekonomi. Hasil penelitian ini sejalan dengan Gigante (2013); Bayraktaroglu, Calisir and Baskak (2019); Dalwai and Mohammadi (2020), namun tidak sejalan dengan penelitian yang dilakukan oleh 
Muhammad and Ismail (2009); Puntilo (2019) yang menyatakan bahwa kinerja bank tidak ada hubungan dan tidak terlalu di tentukan oleh efisiensi IC

\section{Kesimpulan}

Intellectual Capital (IC) adalah salah satu pendorong penting penciptaan nilai ekonomi berbasis pengetahuan bagi sebuah perusahaan dalam hal ini Bank. Dengan IC dapat menciptakan nilai ekonomi berbasis pengetahuan, sebagai sumber keunggulan kompetitif sehingga dapat mempengaruhi kreatifitas dan nilai bagi pemangku kepentingan. Berdasarkan hasil analisis dan pembahasan, kesimpulan yang dapat diambil dari penelitian adalah bahwa ketiga komponen dari model VAIC yaitu Human Capital Efeciency (HCE) berpengaruh terhadap ROA, Capital Employed Efeciency (CEE) berpengaruh terhadap ROA. Structural Capital Efeciency (SCE) berpengaruh terhadap ROA, dan VAIC secara simultan berpengaruh terhadap ROA.

Keterbatasan dari penelitian ini adalah dalam mengukur IC hanya menggunakan 1 variabel saja yaitu ROA sebagai variabel independen, sehingga untuk penelitian selanjutnya bisa menambahkan beberapa variabel dependen seperti ROE, ROI, MBV, Size dan lain sebagainya.

\section{Daftar Pustaka}

Asiaei, K., \& Jusoh, R. (2015). A multidimensional view of intellectual capital: the impact on organizational performance. Management Decision, 53(3), 668-697.

Aslam, E., \& Haron, R. (2020). Corporate governance and banking performance: the mediating role of intellectual capital among OIC countries. Corporate Governance (Bingley). https://doi.org/10.1108/CG-08-2020-0312

Bayraktaroglu, A. E., Calisir, F., \& Baskak, M. (2019). Intellectual capital and firm performance: an extended VAIC model. Journal of Intellectual Capital, 20(3), 406425. https://doi.org/10.1108/JIC-12-2017-0184

Bollen, L., Vergauwen, P., \& Schnieders, S. (2005). Linking intellectual capital and intellectual property to company performance. Management Decision, 43(9), 1161-1185. https://doi.org/10.1108/00251740510626254

Bontis, N. (1998). Mapping the human capital management research trends using bibliometric analysis. Management Decision, 32(6), 63-76.

Brennan, N. (2001). Reporting intellectual capital in annual reports: evidence from Ireland. Accounting, Auditing \& Accountability Journal, 14(4), 423-436. https://doi.org/10.21002/icmr.v1i2.3653

Celenza, D., \& Rossi, F. (2014). Intellectual capital and performance of listed companies: Empirical evidence from Italy. Measuring Business Excellence, 18(1), 22-35. https://doi.org/10.1108/MBE-10-2013-0054

Chang, S.-L. (2007). Valuing Intellectual Capital and Firms' Performance: Modifying Value Added Intellectual Coefficient (VAIC ${ }^{\mathrm{TM}}$ ) in Taiwan IT Industry. ProQuest, 123.

Chen, Danbolt, J., \& Holland, J. (2014). Rethinking bank business models: The role of intangibles. Accounting, Auditing and Accountability Journal, 27(3), 563-589. https://doi.org/10.1108/AAAJ-11-2012-1153

Chen, M. C., Cheng, S. J., \& Hwang, Y. (2005). An empirical investigation of the relationship between intellectual capital and firms' market value and financial performance. Journal of Intellectual Capital, 6(2), 159-176. https://doi.org/10.1108/14691930510592771 
Dalwai, T., \& Mohammadi, S. S. (2020). Intellectual capital and corporate governance: an evaluation of Oman's financial sector companies. Journal of Intellectual Capital, 21(6), 1125-1152. https://doi.org/10.1108/JIC-09-2018-0151

Do Rosário Cabrita, M., \& Bontis, N. (2008). Intellectual capital and business performance in the Portuguese banking industry. International Journal of Technology Management, 43(1-3), 212-237. https://doi.org/10.1504/IJTM.2008.019416

Dzenopoljac, V., Yaacoub, C., Elkanj, N., \& Bontis, N. (2017). Impact of intellectual capital on corporate performance: Evidence from the Arab region. Journal of Intellectual Capital, 2(1).

Firer, S., \& Mitchell Williams, S. (2003). Intellectual capital and traditional measures of corporate performance. Journal of Intellectual Capital, 4(3), 348-360. https://doi.org/10.1108/14691930310487806

Garcia-Perez, A., Ghio, A., Occhipinti, Z., \& Verona, R. (2020). Knowledge management and intellectual capital in knowledge-based organisations: a review and theoretical perspectives. Journal of Knowledge Management, 24(7), 1719-1754. https://doi.org/10.1108/JKM-12-2019-0703

Gigante, G. (2013). Intellectual Capital and Bank Performance in Europe. Accounting and Finance Research, 2(4), 120-129. https://doi.org/10.5430/afr.v2n4p120

Guthrie, J., \& Petty, R. (2000). Intellectual capital: Australian annual reporting practices. Journal of Intellectual Capital, 1(3), 241-251. https://doi.org/10.1108/14691930010350800

Guthrie, J., Petty, R., \& Johanson, U. (2001). Sunrise in the knowledge economy: Managing, measuring and reporting intellectual capital. Accounting, Auditing \& Accountability Journal, 14(4), 365-384. https://doi.org/10.1108/EUM0000000005869

Haris, M., Yao, H., Tariq, G., Malik, A., \& Javaid, H. (2019). Intellectual Capital Performance and Profitability of Banks: Evidence from Pakistan. Journal of Risk and Financial Management, 12(2), 56. https://doi.org/10.3390/jrfm12020056

Herrera Rodríguez, E. E., \& Ordóñez-Castaño, I. A. (2020). Disclosure of intangible liabilities: comparative study of the banking sectors in Panama and Colombia. Journal of Applied Accounting Research, 21(4), 635-656. https://doi.org/10.1108/JAAR-09-2018-0157

Inkinen, H. (2015). Review of empirical research on intellectual capital and firm performance. Journal of Intellectual Capital, 16(3), 518-565.

Isola, W. A., Adeleye, B. N., \& Olohunlana, A. O. (2020). Boardroom female participation, intellectual capital efficiency and firm performance in developing countries: Evidence from Nigeria. Journal of Economics, Finance and Administrative Science, 25(50), 413-424. https://doi.org/10.1108/JEFAS-03-2019-0034

Kannan, G., \& Aulbur, W. G. (2004). Intellectual capital: Measurement effectiveness. Journal of Intellectual Capital, 5(3), 389-413. https://doi.org/10.1108/14691930410550363

Klein, D. A., \& Prusak, L. (1994). characterizing intellectual capital. center for Business innovation. Ernst \& Young LLP Working Paper, new York.

Lari Dashtbayaz, M., Salehi, M., Mirzaei, A., \& Nazaridavaji, H. (2020). The impact of corporate governance on intellectual capitals efficiency in Iran. International Journal of Islamic and Middle Eastern Finance and Management, 13(4), 749-766. https://doi.org/10.1108/IMEFM-11-2017-0291

Mondal, A., \& Ghosh, S. K. (2012). Intellectual capital and financial performance of Indian banks. Journal of Intellectual Capital, 13(4), 515-530. https://doi.org/10.1108/14691931211276115

Muhammad, N. M. N., \& Ismail, M. K. A. (2009). Intellectual Capital Efficiency and Firm's Performance: Study on Malaysian Financial Sectors. International Journal of 
Economics and Finance, 1(2). https://doi.org/10.5539/ijef.v1n2p206

Nadeem, M., Gan, C., \& Nguyen, C. (2018). The Importance of Intellectual Capital for Firm Performance: Evidence from Australia. Australian Accounting Review, 28(3), 334344. https://doi.org/10.1111/auar.12184

Nazari, J. A., \& Herremanas, I. M. (2007). "Extended VAIC model: measuring intellectual capital components. Journal of Intellectual Capital, 8(4), 595-609.

Ousama, A. A., Hammami, H., \& Abdulkarim, M. (2019). The association between intellectual capital and financial performance in the Islamic banking industry: An analysis of the GCC banks. International Journal of Islamic and Middle Eastern Finance and Management, 13(1), 75-93. https://doi.org/10.1108/IMEFM-05-2016-0073

Ozkan, N., Cakan, S., \& Kayacan, M. (2016). "Intellectual Capital and financial performance: a study of the Turkish banking sector. 20, 1-9.

Pulic, A. (2000). VAIC ${ }^{\mathrm{TM}}$ - An Accounting Tool for Intellectual Capital Management. International Journal Technology Management, 20(5/6/7/8), 702-714.

Pulic, A. (2004). Intellectual capital - does it create or destroy value? Measuring Business Excellence, 8(1), 62-68. https://doi.org/10.1108/13683040410524757

Puntilo, P. (2019). Intellectual Capital and business performance . Evidence from Italian banking industry. Journal of Corporate Finance, 12(4), 97-115.

Ramírez, Y., Dieguez-Soto, J., \& Manzaneque, M. (2020). How does intellectual capital efficiency affect firm performance? The moderating role of family management. International Journal of Productivity and Performance Management. https://doi.org/10.1108/IJPPM-03-2019-0119

Roslender, R., \& Fincham, R. (2004). Intellectual capital accounting in the UK: A field study perspective. Accounting, Auditing \& Accountability Journal, 17(2), 178-209. https://doi.org/10.1108/09513570410532429

Salinas-Ávila, J., Abreu-Ledón, R., \& Tamayo-Arias, J. (2020). Intellectual capital and knowledge generation: an empirical study from Colombian public universities. Journal of Intellectual Capital, 21(6), 1053-1084. https://doi.org/10.1108/JIC-092019-0223

Scafarto, V. (2016). Intellectual capital and firm performance in the global agribusiness industry: the moderating role of human capital. Journal of Intellectual Capital, 17(3).

Shahwan, T. M., \& Habib, A. M. (2020). Does the efficiency of corporate governance and intellectual capital affect a firm's financial distress? Evidence from Egypt. Journal of Intellectual Capital, 21(3), 403-430. https://doi.org/10.1108/JIC-06-2019-0143

Shiu, H. (2006). Application of the VAIC method to measures of corporate performance: a quantile regression approach. Journal of American Academy, 156-161.

Sidharta, I., \& Affandi, A. (2016). The empirical study on intellectual capital approach toward financial performance on rural banking sectors in Indonesia. International Journal of Economics and Financial Issues, 6(3), 1247-1253.

Smriti, N., \& Das, N. (2018). The impact of intellectual capital on firm performance: a study of Indian firms listed in COSPI. Journal of Intellectual Capital, 19(5), 935-964. https://doi.org/10.1108/JIC-11-2017-0156

Sorongan, F. A. (2016). Factors Affecting the Return Stock Company in Indonesia Stock Exchange (IDX) LQ45 in Years 2012-2015. The Winners, 17(1), 37. https://doi.org/10.21512/tw.v17i1.1808

Sorongan, F. A. (2019). Pengaruh Return on Assets, Return on Equity, Earning Per Share Terhadap Harga Saham Pada Perusahaan Otomotif Yang Terdaftar Bei. JMBI UNSRAT (Jurnal Ilmiah Manajemen Bisnis Dan Inovasi Universitas Sam Ratulangi)., 6(2), 106-114. https://doi.org/10.35794/jmbi.v6i2.26287 
Subanidja, S., Legowo, M. B., Sorongan, F. A., \& Wahyudi, E. (2020). The Choice of Collaborating with Fintech Entities for Competitive Advantage through Leadership Styles. Scientific Papers of the University of Pardubice, Series D: Faculty of Economics and Administration, 28(3). https://doi.org/10.46585/sp28031092

Tan, H. P., Plowman, D., \& Hancock, P. (2007). Intellectual capital and financial returns of companies. Journal of Intellectual Capital, 8(1), 76-95. https://doi.org/10.1108/14691930710715079

Ting, I. W. K., Ren, C., Chen, F. C., \& Kweh, Q. L. (2020). Interpreting the dynamic performance effect of intellectual capital through a value-added-based perspective. Journal of Intellectual Capital, 21(3), 381-401. https://doi.org/10.1108/JIC-05-20190098

Tran, N. P., Van, L. T. H., \& Vo, D. H. (2020). The nexus between corporate governance and intellectual capital in Vietnam. Journal of Asia Business Studies, 14(5), 637-650. https://doi.org/10.1108/JABS-01-2020-0007

Tunc Bozbura, F. (2004). Measurement and application of intellectual capital in Turkey. The Learning Organization, 11, 357-367. https://doi.org/10.1108/09696470410538251

Wang, Z., Cai, S., Liang, H., Wang, N., \& Xiang, E. (2018). Intellectual capital and firm performance: the mediating role of innovation speed and quality. International Journal of Human Resource Management, O(0), 1-29. https://doi.org/10.1080/09585192.2018.1511611 